Khaled Adnan Oweis,

Associate professor, Northern Border University, Kingdom of Saudi Arabia

Odai Falah Alghaswyneh,

Northern Border University, Kingdom of Saudi Arabia

\title{
THE ANTECEDENTS OF ELECTRONIC BANKING ADOPTION IN SAUDI ARABIA: USING DIFFUSION OF INNOVATION THEORY
}

\begin{abstract}
Despite the rapid growth in technology and the research effort given on investigating the adoption of electronic banking services, both banks and academic researchers in developing countries perceive the problem of low-level adoption of electronic banking. Most studies which have investigated the adoption, acceptance, or intention to use electronic banking, have agreed that customers «trust is one of the most important impediments that have frustrated the success of the adoption process. Therefore, in developed countries, customers» trust became the pivot of research studies that investigated the electronic dealings between customers and new IT/IS innovations. Recently, a few researchers have started investigating online trust in developing countries. Although electronic banking services have been widely adopted in developed countries, there is still low usage in developing countries such as Saudi Arabia. This quantitative research aims to empirically determine the significant antecedents of electronic Banking Service Adoption, as well as to explain how the Diffusion of Innovation Theory (DOIT) is being used in determining the antecedent of electronic banking in Saudi Arabia. Using an adopted survey instrument, (5-point-Likert scale) is used. Were eventually used to further analyse the data using mainly The Partial Least Square (PLS). This study contribute to the body of knowledge by extending existing literature to identifying the factors influencing the acceptance of electronic banking among banks customers, developing a comprehensive model which contributes to online customer literature by extending the Diffusion of Innovation Theory (DOIT) to include trust and system reliability applying them to the context of electronic banking, extending existing literature by applying the developed model to Saudi customers, contributing to technology acceptance theories by showing the role of system reliability in the acceptance of electronic banking, Contributing to the electronic trust literature by examining the role of customer trust in the context of electronic banking and how it might be increased.
\end{abstract}

Keywords: electronic banking services, developing countries, Diffusion of Innovation Theory, trust, partial least square.

Introduction. Saudi Arabia banks have been trying to adopt new technologies to provide updates services to the government, and both private and public institutions (Tan \& chew, 2016). The requirement is for the banks to adopt new technologies like e-commerce activities and internet technology service to meet the needs of the public and private banking systems (Teka \& Sharma, 2017).

Computer technology development and subsequently, the development of the Internet in the past century have led to the creation of a new communication system. The Internet community was introduced to the World Wide Web, a network employed to provide and access information online and following the launching of Internet browsers, the World Wide Web has proliferated all over the globe (Zahir \& Gharleghi, 2014). The power of the Web is evidenced in the educational sector using e-Learning, in governments by the use of e-government, and in banks by the use of e-banking. To leverage the advantages of such eservices, user and organization circles alike must cooperate to realize the highest participation and interaction levels.

Besides, this innovation was expediently taken up by financial organizations, with constant enhancements made on the delivery of financial services. The main aim of the activity is to mitigate the marginal cost for every financial transaction to bring about cost savings, and accordingly, banks developed new channels of service delivery (Aljaafreh et al., 2015). Although the majority of bank customers are aware of the e-banking transactions, the percentage rate of e-banking services use in developing nations is still low (Zahir \& Gharleghi, 2014).

Cite as: Oweis, K. A., Alghaswyneh, O. F. (2019). The Antecedents of Electronic Banking Adoption in Saudi Arabia: Using Diffusion of Innovation Theory. Marketing and Management of Innovations, 4, 160-171. http://doi.org/10.21272/mmi.2019.4-13 
Moreover, as mentioned, similar to other service organizations, banks have been considerably impacted by the technology evolution, coupled with the competitiveness among banking institutions as a result of which, banks have been attempting to search for the new market to expand to. In this regard, more and more financial institutions provide e-banking products to effectively distribute channels and mitigating transaction costs and expedite the service provision (Zhong \& Nieminen, 2015). Moreover, ebanking has been adopted by banking institutions to develop the banking system, and it has proliferated in the majority of countries. It facilitates the creation of service processes that require few internal resources and hence, minimizes costs. It also provides extensive availability and the potential to reach larger numbers of customers.

Literature Review. Based on the viewpoint of customers, e-banking enables access to financial services with ease and expediency (Aljaafreh et al., 2015; Chauhan and Choudhary, 2015); Romi, 2015). E-banking has led many banks to develop strategies of marketing and IT to remain competitive in the market. In this regard, successful IS implementation largely hinges on the level to which a system is utilized and adopted by the end-users. Although the financial institutions in Saudi have invested significantly in electronic financial services systems, the consumers' adoption of such services have not been as expected - in that they were not as used in a higher rate. Also, while some e-banking services are mature, others are still in their infancy. In literature, the issues of e-banking services adoption have been largely studied but in Saudi, only a few studies have been dedicated to it. This highlights the need to investigate the Internet users' adoption behaviour when it comes to e-banking services, and to determine the potential factors contributing to the e-banking services adoption among Saudi Arabia users. Banks are urged to develop, maintain and improve their e-banking services provision to achieve competitive advantage and form a niche in a highly competitive banking market, sustain revenues growth, obtain new customers and retain old ones, achieving significant savings in costs of transaction and staff (Kumar, 2015). Meanwhile, e-banking is viewed by customers as advantageous primary because of its $24 / 7$ provision of banking services, time-saving, and access from any location where internet connection exists, ease of use and ease of carrying credit (Hellenic Bank Association, 2013). Moreover, e-banking supports the dynamic response to customers' complaints and high services quality (Abu-Shanab \& Al-Azzam, 2012). However, concerns still stem from security in online transactions. According to Gherib (2014), some people are used to face-to-face personal interaction and hence, steer clear of using internet banking where personal interaction is lacking. In 2002, Cap Gemini Ernst and Young predicted that e-commerce initiatives spending would experience over $50 \%$ increase in the following years (CUTAC, 2002), as a single ebanking transaction using bank website only costs $\$ 0.01$. In comparison to traditional banking transactions, this is quite minimal - teller use incurs $\$ 1.07$, telephone transactions incur $\$ 0.54$, and ATM transactions incur $\$ 0.27$ each, while PC software transaction (e.g., Quicken) incurs $\$ 1.50$ for every transaction. Meanwhile, banks only charge online customer's monthly service fee of $\$ 5-\$ 10$ (MsMoney.com Inc. 2002). In the context of Saudi Arabia, banks provide e-banking access without charge to boost the use of this transaction channel. According to Pew Internet and American Life Project, there are several factors affecting e-banking use and they are; convenience, time-saving, enhanced finances control, no need to stand in a queue or interact with bank clerks, cost-saving, and easier information access (Kim, 2012; Yin, 2013). Based on the estimates made by Tower Group (2001), Lin et al. (2011) and Abbad (2011) related that $13 \%$ of U.S. households were active e-banking services users and that by 2015, e-banking will reach over 50 million U.S. households. Such estimation stemmed from the U.S. households having higher-than-average incomes, more investable assets and higher net worth, particularly based on age. Also, 65 million U.S. households were predicted to use e-banking by 2015 (Statistics for Online Banking, 2003). This was backed by the International Data Corporation, which reported a steady increase in the offering of electronic services. True to the prediction, by 1998, 1200 U.S. banks were offering online services constituting 6\% and this increased to $8400(42 \%)$ in 1999, and 12000 
$(61.3 \%)$ in 2000 . Finally, in 2003 , a total of 15,845 (75\%) U.S. banks offered online services. The above discussion and presentation of statistics provide an overview of the U.S. scenario when it comes to ebanking services. In Jordan, on the other hand, the Jordan Times (2001) predicted that e-banking will become a norm in the region within 3-6 years and the banks who do not respond to the changes will lag the rest. In the context of Saudi Arabia, e-banking also experienced low adoption when compared to Western and other Arab countries (e.g., Kuwait with 29\%, the UAE with 21\% and Bahrain with 17\%).

Electronic banking has several benefits for banking and financial institutions as well as for retail customers and commercial ones as described in this section. For banks and financial institutions, the first benefit is the notably decreased transaction costs, where transaction costs refer to the delivery cost of the bank and its facilities. Because of the high cost of mass media advertising in the form of newspaper and television advertisements, this contributes to the increased delivery cost of the bank products. In contrast, through the internet web server, a graphic designer also markets for the banks and because the cost will not be repeated, it is far more useful. Also, advertising is available online for 24 hours and through the website the customers can access the bank any time they want. Banks can recommend their services online as a result of which they can minimize their costs, increase savings and minimize labour. The second bank benefit is higher income in the banks and other institutions of its kind can sell products online through websites, this will advertise their range of products and attract more customers. For retail customers, the first benefit is decreased cost, according to the offered banking products offered at a lower cost online. Another benefit is comfort in that customers can do their bank transactions at the office, at home or any location at any time, also the speed, where web servers and internet service providers come into play. Customers will need a shorter time to make informed decisions when it comes to their financial investments, Moving on to commercial customers, the first benefit has also cost reduction, where customers can leverage lowest prices using various banking products, Another great benefit for general e-banking services users is effectiveness in services use. The internet provides users services with an expedient manner, with businesses allows paying bills via accounts, while earning as much interest as possible for their cash reserves. Market changes can also be monitored from one minute to the next and investments can be made based on profitable timings. The most effective solution, in this case, is the users' awareness and knowledge, and not more money for banking authentication.

The diffusion of innovation theory was first brought forward by Rogers in 1962, where he referred to diffusion as the process through which innovation is relayed via channels throughout time to the social system's members. The model proposed that the adoption rate of innovation is influenced by five factors namely, relative advantage, compatibility, trialability, observability and complexity. Specifically, relative advantage is the level to which an innovation is viewed to be superior to the idea that came before it, compatibility is the level to which an innovation is viewed to be consistent with the present values, prior experiences and the requirements of potential users, complexity is the level to which an innovation is viewed to be difficult to use and understand while trialability is the level to which an innovation may be tested on a limited manner. Lastly, observability is the level to which the innovation outcomes can be noted by others. Notable innovations that have a higher relative advantage, compatibility, trialability and observability and with less complexity are predicted to be adopted faster compared to other innovations (Rogers, 2003). Under this variable, consumer behaviour towards e-banking services is explained. E-banking services adoption is an actual action of consumers and a total of five items were adopted to measure the variable, gauged on a 5-point Likert scale ranging from 1 (strongly disagree) to 5 (strongly agree). Relative advantage is the level to which an innovation is viewed to be superior to its predecessor (Moore \& Benbasat, 1991). Compatibility is the level to which an innovation is viewed to be aligned with the potential adopters' values, past experiences and needs (Moore \& Benbasat, 1991). Moore and Benbasat (1991) referred to complexity as the level to which an innovation is believed to be difficult to utilize. This is the level to which an innovation can be experimented with based on a limited basis (Moore 
\& Benbasat, 1991). Observability was described by Moore and Benbasat (1991) as the level to which the system can be observed by others in the organization and five items were used to measure it.

Methodology and research methods. The data gathered in a quantitative study is analysed using a statistical method and in this study, the Partial Least Squares-Structural Equation Modelling (PLS-SEM) with Smart PLS 3.0 M3 software was used. The PLS model has been extensively utilized in management research as well as all social science fields (Hair et al., 2012; Lee et al., 2011), where authors made use of it for the measurement of estimation relating to the relationship of path models made by latent constructs. PLS-SEM involves two steps namely, the measurement model step and the structural model step. The reliability and validity of data are measured in the former, while the hypotheses are tested in the latter.

This study included customers of some selected Al Rajhi Bank branches as the study population, particularly those banks offering e-banking services located in the Northern Border Region. In this regard, the customers of 20 branches form the population of this study. Each branch asked its staff who work at customer service in the twenty branches chosen to aid the researcher by distributing the questionnaires to the branch customers.

The entire population chosen is homogeneous as the selected branches offer the same services to their customers. (Barney \& Hesterly, 2015), indicated that the homogenous population offers a relaxed opportunity to conduct the sampling procedure and makes easy generalization to the population.

More specifically, the chosen branches consisted of 1,063,928 from a total of 1,989,928 customers of the chosen banks. According to Sekaran and Bougie (2010), if the population exceeds 75,000, then the minimum size of the sample must be 384 . Moreover, based on Roscoe's rule of thumb regarding the sample size, the suitable number of sample units for the majority of studies lies between 30 and 500 (Hill, 1998). Therefore, based on the above rule of thumb, this study's sample size is 384 . This study used a proportionate random sampling procedure for its suitability and its consideration of respondents' heterogeneity and reduction of common survey bias (Jun et al., 2006). The proportionate random sampling method enhances the sample representativeness by minimizing the sampling error as explained in Chen (2015).

Results. The data gathered in a quantitative study is analysed using a statistical method and, in this study, the Partial Least Squares-Structural Equation Modeling (PLS-SEM) with Smart PLS 3.0 M3 software was used. The PLS model has been extensively utilized in management research as well as all social science fields (Hair et al., 2012; Lee et al., 2011), where authors made use of it for the measurement of estimation relating to the relationship of path models made by latent constructs. PLS-SEM involves two steps namely, the measurement model step and the structural model step. Reliability analysis examines the measurement scales properties along with the items comprising them. It gauges the variable's consistency and stability (Sekaran, 2006). The procedure computes commonly used measures of scale reliability and furnishes information on the individual items' relationship with the scale (Teng, 2011). In this study, Cronbach's alpha reliability coefficient was obtained to determine the reliability of both dependent and independent variables via the Likert scale employed. The Cronbach's alpha value is a measurement of the way the items are positively correlated to each other. Reliability coefficient that is nearer to 1.00 is considered to support the goodness of the instrument, while those that are less than 0.6 are poor, and those higher than 0.8 are considered to be good (Sekaran, 2006). The summarized report on the reliability of coefficients is displayed below Table 1.

Zikmund and Babin (2013) referred to validity as the level of the measure's accurate representation of the characteristics being measured. It is a scale that helps in determining that the measurement measures what it is supposed to measure (Pallant, 2010). Validity indicates that the scales used are devoid of random and systematic error (Feinburg et al., 2012). Validity is of two types in PLS-SEM, with the first being convergent validity and the second being discriminant validity. Convergent validity measures the 
effectiveness of the item in reflecting the factors they are measuring (McDonald et al, 2013), whereas discriminant validity measures the statistical difference between two factors (Zikmund \& Babin, 2013). The next sub-sections detail the conditions for the two validity types.

Table 1. The Reliability Coefficients of Variable.

\begin{tabular}{|c|c|}
\hline Reliability Coefficient & Remarks \\
\hline Less than 0.6 & Poor \\
\hline $0.6-0.7$ & Acceptable \\
\hline $0.7-0.8$ & Good \\
\hline 0.9 or more & Excellent \\
\hline
\end{tabular}

Source: developed by the author.

The questionnaire sets were distributed to customers to obtain their opinion on e-banking services adoption. Seven hundred and sixty-eight (768) questionnaire sets were distributed, after which the rate of response was increased through personal visits and self-administration of questionnaires. As a result of such efforts, a total of 563 questionnaires were returned. The response rate obtained is aligned with the definition provided by Jobber (1989). Out of the 563 returned questionnaires, 51 were dropped owing to missing data, and the remaining 512 questionnaires were found to be relevant for further analysis and testing of hypotheses. The response rate was noted at $68.2 \%$ and this is quite reasonable in the social science field. Sekaran (2016) related that a rate of response of $35 \%$ is enough for survey studies in the social science field. Holtom (2008) also stated that a rate of response of $35 \%$ is considered acceptable. Table 2 tabulates the rate of response.

Table 2. Response Rate of the Questionnaire

\begin{tabular}{|c|c|}
\hline Response & Frequency \\
\hline Distributed & 768 \\
\hline Returned & 563 \\
\hline Excluded & 51 \\
\hline Usable & 512 \\
\hline Response Rate & 68.2 \\
\hline
\end{tabular}

Source: developed by the author.

Missing data occur from the failure of the respondent to provide an answer to either one or some questions/items in the questionnaire. This is a situation where a sampled element fails to respond to one or more questions thereby becoming necessary to resolve before the data analysis process (Bultum, 2014). Arguably, missing data turns out to be a problem to be resolved when it becomes impossible to recover the actual missing value (Scheffer, 2002). Various reasons were established for the occurrence of missing data, one of these is the respondent's inability to understand some questions or deliberately decided not to respond (Sekaran \& Bougie, 2010). Pallant (2011) opines that omission by the researcher during data entering also causes missing data. Different techniques of treating missing data have been suggested by scholars. Deb \& Agrawal, (2017) and Hair et al. (2014) supported the ignoring of the treatment of missing data. Takieddine \& Sun (2015) advised against the treatment of missing data, arguing that missing data are treated using different approaches which have varying effects on data analyses. However, certain criteria were suggested by scholars that advocated for the treatment of missing data. For example, Hair et al. (2017) study reveal that any questionnaire with missing data exceeding 15\% should be removed from the data file. This study followed the approach of Hair et al. (2017) and thus removed 16 cases that have more than 15\% missing data. After completing the exercise of dropping the cases with a high percentage of missing data, of Hair et al. (2010) which states that any case of missing 
data with less than $5 \%$ can be treated as such. In the original dataset, there were a total of 23040 data inputs, with 97 missing data, accounting for $0.004 \%$ of the data. There is no consensus. As to the percentage of the missing value that is acceptable to obtain a valid statistical inference. According to researchers $5 \%$ or less missing data rate can be ignored (Schafer, 1999; Tabachnick \& Fidell, 2007). In the present study, the mean replacement was used to address randomly missing values.

Table 3. Missing Values

\begin{tabular}{|c|c|}
\hline Latent Variables & Number of Missing Values \\
\hline Adoption of electronic banking & 14 \\
\hline Relative advantage & 11 \\
\hline Compatibility & 9 \\
\hline Complexity & 5 \\
\hline Trialability & 6 \\
\hline Observability & 6 \\
\hline Total & $\mathbf{5 1}$ \\
\hline
\end{tabular}

Source: developed by the author.

The correlation between the latent independent variables of the study is important as it indicates the level at which a variable can be explained by other variables in the analysis (Hair et al., 2010). According to Pallant (2010), multicollinearity involved the relationship between independent variables. The occurrence of multicollinearity can vehemently jeopardize the quality of estimation of coefficients thereby affecting the statistical significance (Chauhan \& Choudhary, 2015). However, multicollinearity occurs when there is a high correlation between an unobserved latent independent construct and others (Hair et al., 2010). It is an unacceptably high level of intercorrelation among the independent variables to the extent that the effects of the variables cannot be separated Gherib, 2015). The value equal to and greater than $90 \%(r \geq 0.9)$ means that there is multicollinearity among the independent variables (Pallant, 2010). However, a correlation matrix was examined to identify any occurrence of high correlation, that is, multicollinearity among the independent latent variables of this study (Peticca et al., 2016; Peterson, \& Kim, 2013). The presence of multicollinearity should be assessed to ensure that multivariate data analysis method assumptions are met. Multicollinearity refers to the level of the relationship between independent variables in the proposed model (Hair et al., 2011). With the high value of the correlation between variables, then multicollinearity may be present - this often arises in regression analysis which leads to misleading outcomes and difficulty in interpreting variables' effects. Moreover, multicollinearity has also described the presence of high correlation value between the exogenous latent constructs in the model, in which case, the estimation of regression coefficients as well as their statistical significance may be distorted (Hair, Black, Babin, Anderson \& Tatham, 2006). It could lead to an exaggerated value of the standard error of coefficients, which turn, could result in statistically insignificant coefficients (Tabachnick \& Fidell 2007). Several methods have been presented by prior literature for the detection of multicollinearity, among them, being variance inflated factor (VIF) and tolerance (Kumar, 2015). If VIF exceeds 5 and the tolerance value remains less than 0.20 , then there is multicollinearity (Hair et al., 2011).

The VIF and tolerance values obtained from the exogenous variables are tabulated in Table 4 . The values remained below the cut-off laid down by Hair et al. (2011), indicating that the issue of multicollinearity is non-existent.

Hair et al. (2006) claimed that aside from histogram use in confirming data normality, a normality probability plot can be drawn. Data normality can also be determined through the skewness and kurtosis values, in which case, normally distributed data is confirmed when the skewness and kurtosis values lie between -2 and +2 . 
Table 4. Tolerance and Variance Inflation Factors (VIF)

\begin{tabular}{|c|c|c|}
\hline \multirow{2}{*}{ Constructs } & \multicolumn{2}{|c|}{ Collinearity Statistics } \\
\cline { 2 - 3 } & Tolerance & VIF \\
\hline Adoption of Electronic Banking & .611 & 1.637 \\
\hline Relative Advantage & .384 & 2.602 \\
\hline Compatibility & .645 & 1.550 \\
\hline Complexity & .690 & 1.449 \\
\hline Trialability & .744 & 1.345 \\
\hline Observability & .333 & 3.006 \\
\hline
\end{tabular}

Source: developed by the author.

Another take on these values came from Hair et al. (2011) who stated that the skewness values falling outside the range of -1 to +1 are an indication of data that has a skewed distribution. The skewness and kurtosis values are presented in Table 5.

Table 5. Skewness and Kurtosis

\begin{tabular}{|c|c|c|c|c|c|c|}
\hline \multirow{2}{*}{ Variable } & Mean & Std. Deviation & \multicolumn{2}{|c|}{ Skewness } & \multicolumn{2}{c|}{ Kurtosis } \\
\cline { 2 - 7 } & Statistic & Statistic & Statistic & Std. Error & Statistic & Std. Error \\
\hline AEB & 3.4062 & .93380 & -.854 & .111 & .479 & .221 \\
\hline RA & 3.1003 & .88483 & -.289 & .111 & -.827 & .221 \\
\hline COMPT & 3.5107 & .91988 & -.651 & .111 & -.217 & .221 \\
\hline COMPX & 3.0029 & .80546 & .739 & .111 & -.174 & .221 \\
\hline TRI & 3.4727 & .95590 & -.652 & .111 & -.134 & .221 \\
\hline OPS & 3.4877 & .92767 & -.527 & .111 & -.035 & .221 \\
\hline
\end{tabular}

Source: developed by the author.

The author further adds that the standard error is decreased in a large sample, which can inflate the calculated values of skewness and kurtosis. Hence, it justifies using plots for assessing normality as compared to other available methods. Following these recommendations made by Field (2009), a histogram and normal probability plot were examined for ensuring the non-violation of normality assumptions. The collected data for this study follows the normal pattern as all the bars on histogram were closed to the normal curve as given in Figure 1 Therefore, the data of present study does not violate the normality assumption.

The present study ran a detailed descriptive analysis of the respondents' demographic profile, which shows that $39.5 \%$ of the respondents were male, while the remaining $60.5 \%$ were female. As for their ages, $40.6 \%$ of the respondents fell in the age group $31-40$ years of age, $33.4 \%$ fell in the age group below 30 years of age, and $15.2 \%$ were in the age group $41-50$ years of age. Lastly, $10.9 \%$ of the respondents were above 50 years of age. As for their monthly income, $93 \%$ of the respondents earned JD1000 and below, 4.7\% earned between JD1001 and 2000, 1.6\% earned JD2001-300, and finally, 0.6\% earned JD3000 and above. Majority of the respondents had bachelor's degrees (50\%), while the remaining others had master's degrees (14.1\%), PhD (13.1\%) and professional education (22.6\%). Based on the frequency statistics of the demographic variables of respondents, $37.1 \%$ of the total respondents had less than a year experience in using e-banking services, $25.8 \%$ had two years of experience, $20.6 \%$ had three years of experience, while $16.1 \%$ had over three years of experience in using e-banking services. 


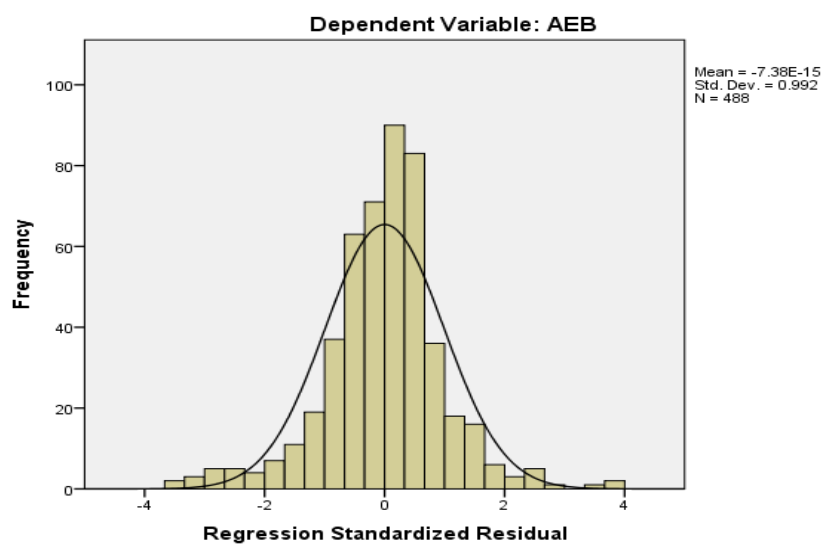

Figure 1. Histogram and normal probability plot

Source: developed by the author.

Overall, the respondents were from different backgrounds and had varying characteristics that form a good representative sample to the population.

Table 6. Demographic Characteristics of the Respondents

\begin{tabular}{|c|c|c|}
\hline Demographic Variables & Frequency & Percentage \\
\hline \multicolumn{3}{|l|}{ Gender } \\
\hline Male & 193 & 39.5 \\
\hline Female & 295 & 60.5 \\
\hline \multicolumn{3}{|l|}{ Age } \\
\hline Below 30 Years & 163 & 33.4 \\
\hline 31-40 Years & 198 & 40.6 \\
\hline 41-50 Years & 74 & 15.2 \\
\hline Above 51 & 53 & 10.9 \\
\hline \multicolumn{3}{|l|}{ Income } \\
\hline Below 1000 JD & 454 & 93.0 \\
\hline $10001-2000 \mathrm{JD}$ & 23 & 4.7 \\
\hline $2100-3000 \mathrm{JD}$ & 8 & 1.6 \\
\hline $3100-4000 \mathrm{JD}$ & 3 & .6 \\
\hline 4100 JD and Above & 454 & 93.0 \\
\hline \multicolumn{3}{|l|}{ Education } \\
\hline Bachelor & 244 & 50.0 \\
\hline Master & 69 & 14.1 \\
\hline $\mathrm{PhD}$ & 65 & 13.3 \\
\hline Others & 110 & 22.5 \\
\hline \multicolumn{3}{|l|}{ E-Banking experiences } \\
\hline & 181 & 37.1 \\
\hline & 126 & 25.8 \\
\hline & 100 & 20.5 \\
\hline & 81 & 16.6 \\
\hline
\end{tabular}

Source: developed by the author. 
The general picture of the tendency of respondents to e-banking adoption was analysed based on compatibility, complexity, trialability, observability, system reliability, service visibility and perceived trust. Table -6 shows the mean and standard deviation values, where the minimum value of the entire constructs is 1.00 , and the maximum is 5.00 , representing the Likert scale utilized. Data shows that compatibility and adoption of e-banking obtained the maximum mean of 3.51 and 3.4 respectively (with a standard deviation of 0.805 , and 0.933 respectively. The results show that the respondents tended to have high adoption levels of e-banking services.

Table 7. Descriptive Statistics for Latent Variables

\begin{tabular}{|c|c|c|}
\hline Construct & Mean & S. Deviation \\
\hline Adoption of electronic banking & 3.4062 & .93380 \\
\hline Relative advantage & 3.1003 & .88483 \\
\hline Compatibility & 3.5107 & .91988 \\
\hline Complexity & 3.0029 & .80546 \\
\hline Trialability & 3.4727 & .95590 \\
\hline Observability & 3.4877 & .92767 \\
\hline
\end{tabular}

Source: developed by the author.

The relative advantage of innovation represents the perception level of its superiority over the idea that came before it (Rogers, 2003). Roger's theory proposes that new technology's relative advantage encourages the rate of its adoption. E-banking studies in prior literature indicated the positive and significant influence of relative advantage on e-banking services adoption (e.g., Lee, 2011; Thambiah et al., 2011; Lu et al., 2011; Chen., 2015) and therefore, this study proposes the following hypothesis for testing:

$\mathrm{H} 1$ : Relative advantage has a positive influence on the adoption of e-banking services.

$\mathrm{H} 2$ : Compatibility positively influences the electronic banking services adoption.

$\mathrm{H} 3$ : Complexity has a negative influence on e-banking services adoption.

$\mathrm{H} 4$ : Observability positively influences the electronic banking services adoption.

H5: Trialability positively influences the electronic banking services adoption.

Table 8. Structural Model Assessment

\begin{tabular}{|c|c|c|c|c|}
\hline Hypothesis & Path coefficient & T value & P-value & Decision \\
\hline H1 & 0.126 & 2.65 & 0.042 & Supported \\
\hline H2 & 0.169 & 3.16 & 0.001 & Supported \\
\hline H3 & -0.293 & 4.88 & 0.000 & Supported \\
\hline H4 & 0.004 & 0.11 & 0.457 & Not Supported \\
\hline H5 & 0.529 & 9.97 & 0.000 & Supported \\
\hline
\end{tabular}

Source: developed by the author.

First, in the first hypothesis $\left(\mathrm{H}_{1}\right)$, it was proposed that relative advantage has a significant relationship to e-banking adoption and based on the path coefficient, $t$-value and $p$-value $(\beta=0.126, t=2.65, p=0.042)$, the hypothesis is supported. Additionally, the results evidenced a significant relationship between compatibility and e-banking adoption ( $\beta=0.169, t=3.16, p=0.001)$, supporting $\mathrm{H}_{2}$ and a negative and significant relationship between complexity and e-banking adoption ( $\beta=-293, t=4.88, p=0.000)$, supporting $\mathrm{H}_{3}$. The study also proposed the positive and significant relationship between observability and e-banking adoption, but the results indicated no significant relationship between the two $(\beta=0.004, t=0.109, p=0.457)$, and therefore, $\mathrm{H}_{4}$ is rejected. Moreover, trialability was supported by the results in its significant relationship with e-banking services adoption, indicating support for $\mathrm{H}_{5}$. 
Conclusions. Moreover, future research could conduct more related studies in electronic banking settings in Saudi Arabia, since only a few past studies are investigating the electronic banking in Saudi Arabia, or a comparative study could be conducted to compare between Saudi Arabia and other countries using electronic banking. Since this study was based on DOIT theory, future research could extend this theory and apply it in a new version in electronic banking, or other technology acceptance theories could be applied in the Saudi Arabia context. The researcher used only one instrument, a questionnaire survey. Thus, the researcher suggests that the qualitative method - in-depth interview - could be a suitable way to find more factors that could influence bank customers toward electronic banking services in Saudi Arabia. This can be better achieved when the researcher builds a trusted relationship with them and speaks their language. The current study has targeted actual users of electronic banking services and reported the important features motivating their engagement in electronic banking adoptions in the Saudi Arabia context. The same approach may also be applied to non- users in a quest for pointing out areas of design quality that need improvement or increased interactivity to overcome non-users' apprehension. The present study is the first that provides a deeper understanding of the influence of task technology fit on adopting internet banking. The results of Additional research are required to confirm the influence of these dimensions on accepting other internet technologies, such as electronic government or online shopping. The present study reports a low variance in behavioural intentions towards the use of electronic banking. Therefore, further research should attempt to enhance the explanatory power of the proposed model in this study. One way to increase the explanatory power of the model is to incorporate other issues found in previous research affecting internet banking acceptance, such as perceived user resources and customer loyalty Due to the lack of studies conducted in the Saudi Arabia environment regarding the acceptance of new technologies, the proposed model in the present study can serve as a blueprint for further exploratory research. As an instrument now exists that can be used in the Arabic environment, additional research is encouraged to validate the instrument in different settings, such as online shopping. Moreover, more accurate measurements could be used to clarify whether bank customers are heavy or dormant users of electronic banking. It is recommended for future research that to reach the dormant users of internet banking will depend on objective measures (frequency recorded by the computerized system of a bank). A final suggestion for future research would be to conduct longitudinal research to find out whether the customer's behaviour toward the use of internet banking will change over time. This could investigate the conceptual model developed in the present study in different periods and make comparisons, consequently providing more insight into the phenomenon of the acceptance of internet banking services.

Author Contributions: Conceptualization, writing-original draft preparation; writing-review and editing, K. O., O. A.

Funding. the grant BA-2017-1-7-F-6962, from the Deanship of Scientific Research in Northern Border University, Box: 1321, Arar, P.O. 91431 Saudi Arabia.

\section{References}

Al-Jaafreh, A., Al-Ani, A., Aladaileh, R., \& Al-Jaafreh, R. (2015). Initial trust in internet banking service in Jordan: modeling and instrument validation. Journal of Theoretical and Applied Information Technology, 74

Allison, C. (2016). Technology Acceptance and Course Completion Rates in Online Education: A Non-experimental, Mixed Method Study (Doctoral dissertation, Northcentral University).

Barney, J. B., \& Hesterly, W. S. (2015). Strategic management and competitive advantage: Concepts and cases. Upper Saddle River, NJ: Prentice-Hall.

Bultum, A, G. (2014). Factors affecting adoption of the electronic banking system in Ethiopian banking industry. Journal of Management Information System and ECommerce, 1(1), 1-17. DOI:10.15640/jmise. 
Chauhan, V. \& Choudhary, V. (2015). Internet banking: challenges and opportunities in Indian context. Journal of Management Sciences and Technology 2(3)

Chauhan, V., \& Choudhary, V. (2015). Internet Banking: Challenges and Opportunities In Indian Context. Journal of Management Sciences and Technology, 2(3), 29-40.

Chen, B., Zhang, T., Bond, T., \& Gan, Y. (2015). Development of a quantitative structure-activity relationship (QSAR) model for disinfection byproduct (DBP) research: A review of methods and resources. Journal of Hazardous Materials, 299, 260-279. DOI:10.1016/j.jhazmat.2015.06.054.

Chen, C. (2013). Perceived risk, usage frequency of mobile banking services. Managing Service Quality: An International Journal, 23(5), 410-436.

Deb, M., \& Agrawal, A. (2017). Factors impacting the adoption of m-banking: understanding brand India's potential for financial inclusion. Journal of Asia Business Studies, 11(1), 22-40. DOI:10.1108/JABS-11-2015-0191.

Gherib, D. (2014). Adoption and diffusion of internet banking: case of Tunisian banking sector. Global Business Research Journal, 3(6), 1-29.

Gherib, D. (2015). Top management characteristics and adoption of internet banking: case study of the Tunisian banking sector International Journal of Innovation and Applied Studies, 10(1),377-383.Retrievedfromhttp://www.ijias.issrjournals.org/abstract.php?article=|JIAS-14-282-02.

Hair et al, 2010 Hair, J. F., Black, W. C., Babin, B. J., \& Anderson, R. E. (2010). Multivariate data analysis: A global perspective (7th ed.). Upper Saddle River, NJ: Pearson Education.

Hair, J.F., Sarstedt, M., Pieper, T.M. \& Ringle, C.M. (2012). The use of partial least squares structural equation modeling in strategic management research: a review of past practices and recommendations for future applications. Long Range Planning, 45 320-340.

Kumar, P. R., \& Varaiya, P. (2015). Stochastic systems: Estimation, identification, from 7th international conference on Electronic commerce, 113, 195-200.

Kim, H., \& Hoskisson, R. E. (2015). A resource environment view of competitive advantage. Journal of Mixed Methods Research, 1-16. DOI:10.1177/1558689816651032

Lee, H., Harindranath, G., Oh, S., \& Kim, D. J. (2015). Provision of mobile banking services from an actor-network perspective: Implications for convergence andstandardization. Technological Forecasting and Social Change, 90, 551-561. doi: 10.1016/j.techfore.2014.02.007

Lee, K. W., Tsai, M. T., \& Lanting, M. C. (2011). From marketplace to marketspace: Investigating the consumer switch to online banking. Electronic Commerce Research and Application, 10, 115-125.

Lu, M., Hu, S., Huang, L., \& Tzeng, G. (2015). Evaluating the implementation of business-to-business m-commerce by SMEs based on a new hybrid MADM model. Management Decision, 53, 290-317. DOI:10.1108/MD-01-2014-0012

Lu, Y., Cao, Y., Wang, B., \& Yang, S. (2011). A study on factors that affect users' behavioral intention to transfer usage from the offline to the online channel. Computers in Human Behavior, 27(1), 355-364.

McDonald, K. E., Kidney, C. A., \& Patka, M. (2013). «You need to let your voice beheard»: Research participants' views on research. Journal of Intellectual Disability Research, 57, 216-225. DOI:10.1111/j.1365-2788.2011.01527.x.Moore, G. C., \& Benbasat, I. (1990). An Empirical Examination of the Adoption of Information Technology by End-users: A Diffusion of Innovations Perspective. Calgary, Canada: University of Calgary.

Moore, G.C., \& Benbasat, I. (1991). Development of an instrument to measure the perceptions of adopting an information technology innovation. Information Systems Research, 2(3), 192-222.

Pallant, J. (2011). SPSS survival manual: a step by step guide to data analysis using SPSS (4th ed.). England: Open University Press.

Peterson, R. A., \& Kim, Y. (2013). On the relationship between coefficient alpha and composite reliability. Journal of Applied Psychology, 98(1), 194.

Peticca-Harris, A., deGama, N., \& Elias, S. R. S. T. A. (2016). A dynamic process model for finding informants and gaining access in qualitative research.Organizational Research Methods, 19, 159-347. DOI:10.1177/1094428116629218.

Rogers, E.M. 2003, Diffusion of innovations, Free press, New York. International Journal of Bank Marketing, 21(6/7), 312-323.

Schafer, J. L. (1999). Multiple imputation: a primer. Statistical methods in medical revolution? Retrieved from http://www.pwc.com/banking.html.

Sekaran, U., \& Bougie, R. (2010). Research methods for business: A skill-building approach. (5th ed.). New York: John Wiley and Sons, Inc.

Sekaran, U., \& Bougie, R. (2013). Research methods for business: A skill-building approach. (6th ed.). New York: John Wiley and Sons, Inc.

Shafeey, T., \& Trott, P. (2014). Resource-based competition: Three schools of thought and thirteen criticisms. European Business Review, 26, 122-148. DOI:10.1108/EBR-07-2013-0096.

Takieddine, S., \& Sun, J. (2015). Internet banking diffusion: A country-level analysis. Electronic Commerce Research and Applications, 14, 361-371. DOI:10.1016/j.elerap.2015.06.001.

Teka, B. M., \& Sharma, D. (2017). Influence of demographic factors on users' adoption of electronic banking in Ethiopia. Journal of Internet Banking and Commerce, 22(S7), 1. Retrieved from http://www.icommercecentral.com 
Zahir Irani, P., Basias, N., Themistocleous, M., \& Morabito, V. (2013). SOA adoption in e-banking. Journal of Enterprise Information Management, 26, 719-739. DOI:10.1108/JEIM-07-2013-0042

Zahir, M., \& Gharleghi, B. (2014). Adoption of internet banking in Maldives, the most important determinants. Asian Social Science, 11(2)

Zahir, M., \& Gharleghi, B. (2015). Adoption of Internet Banking in Maldives, the Most

Zeithaml, V., A., \& Bitner, M. J. (2000). Services Marketing: Integrating Customer Focus across the Firm. Boston, MA: McGrawHill College.

Халед Аднан Овейс, доцент, Північний прикордонний університет (Саудівська Аравія);

Одай Фалах Алгасвіне, Північний прикордонний університет (Саудівська Аравія).

Передумови впровадження електронного банкінга в Саудівській Аравії: теорія дифузії інновацій

Стрімке зростання популярності інтернет-технологій та кількості наукових праць, що досліджують особливості впровадження електронних банківських послуг обумовлюють актуальність дослідження. При цьому авторами зазначено, що в країнах, які розвиваються, рівень запровадження електронного банкінгу є низьким. Переважна більшість досліджень сфокусовано на аналізі рівня довіри клієнта як основного фрактору, що стримує розвиток та поширення електронного банкінгу. Так, у розвинених країнах довіра клієнтів є ключовим об'єктом наукових досліджень при аналізі ефрективності електронних комунікацій між клієнтами та інноваціями IT/IS. Авторами зазначено, що послуги електронного банкінгу широко застосовуються в розвинених країнах, тоді як у країнах, що розвиваються, таких як Саудівська Аравія, рівень використання електронного банкінгу є низьким. Основною метою статmі є аналіз та емпіричне обгрунтування факторів-стимуляторів впровадження електронних банківських послуг із урахуванням специфіки Теорії дифузії інновацій (DOIT) при визначенні передумов поширення електронного банкінгу в Саудівській Аравії. Інформаційну базу дослідження склали результати опитування респондентів. У статті застосовано 5-бальна-лікертова шкала. Перевірку висунутих гіпотез здійснено 3 використанням часткового методу найменших квадратів структурних рівнянь - Partial Least Squares-Structural Equation Modelling (PLS-SEM). Відповідно до отриманих емпіричних даних чотири із п'яти висунутих гіпотез дослідження підтверджено, що дає підстави зробити висновок, що на поширення електронного банкінгу позитивно впливають такі фрактори як: зручність, швидкість та відносно легка апробація. При цьому складність та не зрозумілість послуг електронного банкінгу негативно впливають на його поширення. Авторами визначено, що гіпотеза про позитивний вплив можливості постійного контролю на поширення послуг електронного банкінгу не підтвердилась.

Ключові слова: послуги електронного банкінгу, країни, що розвиваються, теорія розповсюдження інновацій, довіра.

Manuscript received: 20.07.2019.

(c) The author(s) 2019. This article is published with open access at Sumy State University. 